\title{
Cattle slurry acidification and application method can improve initial phosphorus availability for maize
}

\author{
Ingeborg F. Pedersen • Gitte H. Rubak • \\ Peter Sørensen
}

Received: 18 August 2016 / Accepted: 22 November 2016 / Published online: 26 November 2016

(C) Springer International Publishing Switzerland 2016

\begin{abstract}
Background and aims The utilization of phosphorus (P) in cattle slurry as a starter fertilizer in maize cropping is poor. To improve this and to obviate the use of additional mineral starter-P fertilization, we examined if slurry acidification, placement strategy and application time could increase maize yield and phosphorus uptake (PU) in the early growth stages.

Methods In a climate-controlled pot experiment, untreated ( $\mathrm{pH}$ 6.5) and acidified $(\mathrm{pH} 5.5$ or $\mathrm{pH} 3.8)$ cattle slurry was injected in narrow or broad bands two or 30 days before sowing of maize on a coarse sandy and a sandy loam soil and compared with mineral $\mathrm{P}$ fertilizer. Results After broad band slurry injection, the $\mathrm{P}$ concentration in maize tissues at the five-leaf stage and the dry matter yield at the seven-leaf stage were equal to or higher than the mineral $\mathrm{P}$ fertilizer treatment. Treatments with strongly acidified slurry (pH 3.8) had 49\% higher PU at the seven-leaf stage compared to untreated slurry, but only on the sandy soil, suggesting an indirect $\mathrm{pH}$ effect on PU. Application time had no effect.

Conclusion Broad band slurry injection or strong acidification can improve early-stage growth of maize and potentially obviate the use of mineral $\mathrm{P}$.
\end{abstract}

Responsible Editor: John A. Kirkegaard.

I. F. Pedersen $(\bowtie) \cdot$ G. H. Rubæk $•$ P. Sørensen

Department of Agroecology, Faculty of Science and Technology, Aarhus University, Blichers Allé 20, PO box 50, 8830 Tjele, Denmark

e-mail: ifp@agro.au.dk
Keywords Acidification - Cattle slurry - Injection . Phosphorus $\cdot$ Silage maize $\cdot$ Starter fertilizer

$\begin{array}{ll}\text { Abbreviations } \\ \text { P } & \text { Phosphorus } \\ \text { N } & \text { Nitrogen } \\ \text { PU } & \text { Phosphorus uptake } \\ \text { DM } & \text { Dry matter } \\ \text { DAS } & \text { Days after sowing } \\ \text { pH 3.8 } & \text { Strongly acidified slurry } \\ \text { pH 5.5 } & \text { Moderately acidified slurry } \\ \text { pH 6.5 } & \text { Untreated slurry } \\ \text { NB } & \text { Narrow band } \\ \text { BB } & \text { Broad band } \\ \text { L } & \text { Late application } \\ \text { E } & \text { Early application } \\ \text { WEP }_{\mathrm{i}} & \text { Dissolved reactive water-extractable P } \\ \text { WEP }_{\mathrm{t}} & \text { Total dissolved water-extractable P } \\ \text { WEP }_{\mathrm{u}} & \text { Dissolved Unreactive water-extractable P } \\ & \end{array}$

\section{Introduction}

Phosphorus $(\mathrm{P})$ is an essential plant nutrient and crucial for future food security (Klinglmair et al. 2015). Mineable rock phosphate, the main source of $\mathrm{P}$ for production of mineral $\mathrm{P}$ fertilizers, is a non- renewable resource (Shepherd et al. 2016), which is very unevenly distributed globally (van Dijk et al. 2016). In developed countries mineral $\mathrm{P}$ is often used in excess, whereas in developing countries $P$ fertilization is often limited because of lacking mineral resources and/or financial 
constraints (Shepherd et al. 2016). The local, the regional and the global P imbalances call for better management strategies of the finite $P$ resource and development of circular economies with minimum use of fertilizers based on rock phosphates and reduced environmental damage (EC 2014; Withers et al. 2015).

Sufficient $\mathrm{P}$ supply from planting to the six-leaf stage can have a large impact on the final crop yield in maize (Barry and Miller 1989). Remobilization of seed-P reserve is completed after one week of growth, and in the critical period hereafter the maize plants are highly dependent on exogenous $\mathrm{P}$ uptake (Nadeem et al. 2011). The low mobility of $P$ in soil combined with the high $\mathrm{P}$ demands from the fast-growing young maize plants with a not yet fully developed root system will often result in sub-optimal P nutrition of maize at this growth stage (Mollier and Pellerin 1999). The release of $\mathrm{P}$ from soil and fertilizer and the diffusion towards the roots will often be too slow to meet the demands of the maize plant (Syers et al. 2008). At the same time, low root zone temperatures in early spring in Northern Europe may further limit growth, since low root zone temperatures reduces both the root growth (Engels and Marschner 1990) and the diffusion rate of $\mathrm{P}$ (Grant et al. 2001). These conditions explain why maize often responds positively to the increase in soluble $\mathrm{P}$ concentrations in the vicinity of the young roots resulting from the application of mineral $\mathrm{P}$ as a starter fertilizer.

In 2015 silage maize was cropped on 183,000 ha in Denmark, corresponding to $7.0 \%$ of the agricultural area. In Denmark maize for silage is typically grown on livestock farms with excess of $\mathrm{P}$ in the supplied manure relative to crop demand. In spite of this, 10$15 \mathrm{~kg} \mathrm{P} \mathrm{ha}{ }^{-1}$ mineral $\mathrm{P}$ fertilizer is routinely placed at the time of sowing to ensure sufficient $P$ supply in the early growing stages (Knudsen 2010), corresponding to $16 \%$ of the annual mineral $P$ fertilizer consumption (14.000 $t$ $P$ in 2014) in Denmark. The resulting $P$ surplus in maize cropping contributes to the accumulation of $\mathrm{P}$ in soil (Rubæk et al. 2013), leading to a higher risk of $P$ losses to the aquatic environment (Kronvang et al. 2009). It is generally accepted that the fertilizer effect of manure $\mathrm{P}$ is $80-100 \%$ of the effect of mineral P fertilizer (e.g. Rubæk and Sibbesen 1995), but some experiments indicate that manure $\mathrm{P}$ is not available to plants shortly after application to soil (Petersen et al. 2010).

The placement of the slurry affects the spatial distribution of $\mathrm{P}$ in the soil, and hence could partially overcome the low mobility of $\mathrm{P}$ and enhance the degree of exposure of slurry $\mathrm{P}$ to the root surface area. According to some studies (e.g. Bittman et al. 2012; Schröder et al. 2015), planting maize close to an injection band can promote early P uptake and growth of maize. However, Sawyer and Hoeft (1990) found an unfavorable root growth environment within the cattle manure injection zone, which could be due to the formation of phytotoxic organic acids under local anaerobic conditions in this zone (Lynch 1980), which may inhibit maize growth. To ensure a large contact zone between the roots and the slurry $\mathrm{P}$ and at the same time avoid unfavorable root conditions in a concentrated manure band, we speculated that injection of the slurry in a broad band with maize planted above the injection band could be advantageous, but we have found no studies reporting this approach.

Slurry acidification can minimize ammonia volatilization (e.g. Fangueiro et al. 2015; Kai et al. 2008) and increase the amount of dissolved $\mathrm{P}$ in manure (Christensen et al. 2009; Fordham and Schwertmann 1977). Since the solubility of manure inorganic $P$ is pH dependent (Pagliari 2014), acidification may improve $\mathrm{P}$ availability in manure and the suitability of manure as a replacement for mineral $\mathrm{P}$ as a starter fertilizer. However, the $\mathrm{pH}$ and the buffer capacity of the soil might be important moderators of the initial effect of slurry acidification. Little is known about how strong the acidification has to be in order to improve $\mathrm{P}$ availability and enhance early maize growth, and even less is known about how these effects are moderated by different soil types and soil properties.

In practice, mineral $\mathrm{P}$ fertilizer is applied at the time of maize sowing. Applying slurry in advance of sowing could be beneficial since it would allow organic $P$ compounds as well as compounds unfavorable for root growth to mineralize before plant emergence (Lynch 1980; Oberson and Joner 2005).

The question is whether it is possible to obviate the use of mineral $\mathrm{P}$ fertilizer by treating and applying manure $P$ in a manner and time that would supply sufficient readily-available manure $P$ to young maize plants and hence avoid over-fertilization and crop deficiencies of $\mathrm{P}$. The aim of the present pot experiment was to study effects of cattle slurry acidification, application technique and application time on maize yield and $\mathrm{P}$ uptake (PU) at early growth stages compared with using mineral P starter fertilizer.

We hypothesized that: 1) Placement of slurry in a broad fertilizer band would improve early maize growth compared to placement in a narrow band; 2) acidification 
of cattle slurry would increase the P solubility, providing a higher availability of exogenous $\mathrm{P}$ to maize and hence a better early maize growth; and 3) application of cattle slurry in advance of sowing would increase the $\mathrm{P}$ availability because the organic $\mathrm{P}$ compounds can be mineralized and made plant-available and/or growth-inhibiting organic substances can be degraded.

\section{Materials and methods}

\section{Design}

The study was conducted in pots in climate-controlled chambers as a fractional factorial experiment with three factors: 1) Acidification of cattle slurry (untreated slurry [pH 6.5], moderately acidified slurry [pH 5.5] and strongly acidified slurry [pH 3.8]), 2) application technique (narrow band [NB] or broad band [BB] injection) and 3) application time (two or 30 days before sowing, only tested for the narrow band injection). In total, nine different combinations with cattle slurry and two reference treatments receiving mineral $\mathrm{N}$ with and without mineral $\mathrm{P}$ fertilizer were tested (Table 1). The pot treatments were set up in a randomized completeblock design with three replicates. To minimize the positional effects in the growth chamber, the pots were re-randomized weekly within each chamber during growth.

Soils and cattle slurry acidification

The treatments were tested on a sandy loam and a coarse sand topsoil $(0-15 \mathrm{~cm})$ typical for maize cropping in Denmark (Table 2). The soils were sieved through a 2$\mathrm{cm}$ sieve and mixed before application to pots.

Cattle slurry was obtained directly from a cattle house with dairy cows in October 2014 at Research Centre Foulum, Aarhus University. The slurry was mixed for three hours in a small tank before sampling and then stored at $2{ }^{\circ} \mathrm{C}$ until use. Acidification of slurry was carried out 32 days before sowing by adding $18 \mathrm{M}$ sulfuric acid $\left(\mathrm{H}_{2} \mathrm{SO}_{4}\right)$ while stirring until $\mathrm{pH}$ was 5.5 and 3.8 , respectively. Slurry $\mathrm{pH}$ tended to increase slightly by storage, and the slurry $\mathrm{pH}$ was adjusted again just before application. In total, $1.70 \mathrm{ml} \mathrm{H}_{2} \mathrm{SO}_{4}$ per $\mathrm{kg}$ cattle slurry was added to reach $\mathrm{pH} 5.5$, and $6.75 \mathrm{ml} \mathrm{H}_{2} \mathrm{SO}_{4}$ $\mathrm{kg}^{-1}$ cattle slurry was added to reach $\mathrm{pH} 3.8$. Slurry properties after acidification are given in Table 3.
Pot preparation and fertilization

The soil was carefully packed and compacted in trapezoidal pots (upper length $27 \mathrm{~cm}$, lower length $24 \mathrm{~cm}$, upper width $14 \mathrm{~cm}$, lower width $12 \mathrm{~cm}$, height $20 \mathrm{~cm}$ ). In each pot $4.8 \mathrm{~kg}$ dry weight soil was added, equivalent to approx. $13 \mathrm{~cm}$ height. Slurry injection was simulated by applying slurry to this lower soil layer in either a 4$\mathrm{cm}$ narrow band (NB) or in a $13-\mathrm{cm}$ broad band (BB, Fig. 1). A furrow was made in the lower soil layer in order to apply slurry in a NB, and an equivalent amount of soil was removed from the BB treatments and added to the upper soil layer. A total of $6.86 \mathrm{~kg}$ dry weight soil was added per pot, and compacted equivalent to an initial bulk density of $1.31 \mathrm{~g} \mathrm{~cm}^{-3}$. The pots were placed in a greenhouse (day temperature $10{ }^{\circ} \mathrm{C}$, night temperature $5{ }^{\circ} \mathrm{C}$ ) until sowing.

Slurry was dosed according to the total $\mathrm{P}$ in slurry at a rate of $57 \mathrm{mg} \mathrm{P} \mathrm{kg}^{-1}$ soil (490 $\mathrm{g}$ fresh slurry to each pot). This corresponds to $20 \mathrm{~kg} \mathrm{Pha}^{-1}$, assuming a distance of $75 \mathrm{~cm}$ between plant rows. Two days before sowing, $389 \mathrm{mg} \mathrm{P}$ was applied as $\mathrm{Na}_{2} \mathrm{HPO}_{4}$ dissolved in $50 \mathrm{ml}$ water to the $20 \mathrm{P}$ treatment. All slurry treatments received $143 \mathrm{mg}$ ammonium-nitrogen $\left(\mathrm{NH}_{4}{ }^{+}-\mathrm{N}\right) \mathrm{kg}^{-1}$ soil in the slurry, corresponding to $50 \mathrm{~kg} \mathrm{NH}_{4}{ }^{+}-\mathrm{N}$ ha ${ }^{-1}$. Taking the expected immobilization of $\mathrm{NH}_{4}{ }^{+}$in the slurry into account, about $40 \mathrm{~kg} \mathrm{NH}_{4}{ }^{+}-\mathrm{N} \mathrm{ha}^{-1}$ in slurry was expected to be available initially and the $0 \mathrm{P}$ and $20 \mathrm{P}$ treatments received $114 \mathrm{mg} \mathrm{NN_{4 }}{ }^{+}-\mathrm{N} \mathrm{kg}^{-1}$ soil as $\left(\mathrm{NH}_{4}\right)_{2} \mathrm{SO}_{4}$ dissolved in $20 \mathrm{ml}$ water corresponding to $40 \mathrm{~kg} \mathrm{NH}_{4}{ }^{+}-\mathrm{N} \mathrm{ha}^{-1}$. The liquid mineral fertilizers were applied to the lower soil layer similar to the placement of slurry in the NB treatments. In total, 20 and $70 \mathrm{ml}$ water was applied in the $0 \mathrm{P}$ and $20 \mathrm{P}$ treatment, respectively.

Before sowing, soil moisture was adjusted to $60 \%$ of the pot capacity (Table 2). Three maize seeds (Zea mays L. var. Adept) were sown per pot at $3 \mathrm{~cm}$ depth and $3 \mathrm{~cm}$ above the fertilizer band (Fig. 1). The pots were placed in a greenhouse until germination (day temperature $15^{\circ} \mathrm{C}$, night temperature $12{ }^{\circ} \mathrm{C}$ ). Non-germinated seeds were replanted with spare maize seedlings. To eliminate other nutrient deficiencies but $\mathrm{P}$ and potential salt damages due to high salt concentrations during germination, additional nutrient solutions were surface-applied twenty-six days after sowing (DAS) at rates (in $\mathrm{mg} \mathrm{kg}^{-1}$ soil) of: $52 \mathrm{~N}$ (as $\mathrm{Mg}\left(\mathrm{NO}_{3}\right)_{2}$ and $\mathrm{KNO}_{3}$ ), $42 \mathrm{~K}$ (as $\mathrm{KNO}_{3}$ ), $8 \mathrm{~S}$ (as $\mathrm{MgSO}_{4}$ ), $1.5 \mathrm{Mn}$ (as $\mathrm{MnSO}_{4}$ ), $1.3 \mathrm{Zn}$ (as $\mathrm{ZnSO}_{4}$ ), 0.6 B (as $\mathrm{H}_{3} \mathrm{BO}_{3}$ ), $1.5 \mathrm{Cu}\left(\right.$ as $\left.\mathrm{CuSO}_{4}\right), 0.02$ $\mathrm{Co}\left(\right.$ as $\left.\mathrm{CoCl}_{2}\right)$ and $0.3 \mathrm{Mo}\left(\right.$ as $\left.\mathrm{NaMoO}_{4}\right)$. 
Table 1 Treatment codes and the combinations of the three factors

\begin{tabular}{llll}
\hline Treatment code & $\begin{array}{l}\text { Acidification } \\
\text { level, slurry pH }\end{array}$ & $\begin{array}{l}\text { Application time, } \\
\text { days before sowing }\end{array}$ & $\begin{array}{l}\text { Application technique, } \\
\text { band width (cm) }\end{array}$ \\
\hline 0P & & 2 (late, L) & \\
20P & & 2 late, L) & \\
pH 3.8 ENB & 3.8 & 30 (early, E) & $4\left(\mathrm{NB}^{\mathrm{a}}\right)$ \\
pH 5.5 ENB & 5.5 & 30 (early, E) & $4(\mathrm{NB})$ \\
pH 6.5 ENB & 6.5 & 30 (early, E) & $4(\mathrm{NB})$ \\
pH 3.8 LNB & 3.8 & 2 late, L) & $4(\mathrm{NB})$ \\
pH 5.5 LNB & 5.5 & 2 late, L) & $4(\mathrm{NB})$ \\
pH 6.5 LNB & 6.5 & 2 (late, L) & $4(\mathrm{NB})$ \\
pH 3.8 LBB & 3.8 & 2 (late, L) & $13\left(\mathrm{BB}{ }^{\mathrm{b}}\right)$ \\
pH 5.5 LBB & 5.5 & 2 (late, L) & $13(\mathrm{BB})$ \\
pH 6.5 LBB & 6.5 & 2 late, L) & $13(\mathrm{BB})$ \\
\hline
\end{tabular}

${ }^{\mathrm{a}} \mathrm{NB}$, Narrow band

${ }^{\mathrm{b}} \mathrm{BB}$, Broad band humidity of $75 \pm 10 \%$. Plants were grown in 16-h photoperiods with light intensities ranging from 170 to 1060 $\mu \mathrm{E} \mathrm{m} \mathrm{m}^{-2} \mathrm{~s}^{-1}$. The pots were irrigated with demineralized water to a water content of $60 \%$ of the pot capacity during the first 35 DAS with increasing frequency from twice weekly to daily. After 35 days the pots were irrigated daily to $70 \%$ of the pot capacity to avoid draught until

Table 2 Characterization of the two soils used for the pot experiment. Standard deviation is given in parentheses $(n=2$, except single point $\operatorname{PSC} n=3$ )

\begin{tabular}{|c|c|c|}
\hline & Coarse sandy soil & Sandy loam \\
\hline Clay $(<2 \mu \mathrm{m})$, g $100 \mathrm{~g}^{-1}$ soil & $3.0(0.4)$ & $6.8(0.3)$ \\
\hline Silt $(2-20 \mu \mathrm{m}),{\mathrm{g} 100 \mathrm{~g}^{-1} \text { soil }}$ & $4.0(0.3)$ & $11.5(0.6)$ \\
\hline Coarse silt $(20-63 \mu \mathrm{m}), \mathrm{g} 100 \mathrm{~g}^{-1}$ soil & $1.9(0.2)$ & $11.3(0.3)$ \\
\hline Fine sand $(63-200 \mu \mathrm{m}),{\mathrm{g} 100 \mathrm{~g}^{-1} \text { soil }}$ & $22.1(0.8)$ & $30.1(0.9)$ \\
\hline 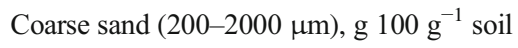 & $66.8(1.5)$ & $38.0(1.5)$ \\
\hline Water content at pot capacity ${ }^{\mathrm{a}}, \%$ & 33 & 34 \\
\hline $\mathrm{pH}$ (water) & $6.3(0.2)$ & $6.5(0.1)$ \\
\hline Bicarbonate extractable $\mathrm{P}^{\mathrm{b}}, \mathrm{mg} 100 \mathrm{~g}^{-1}$ soil & $4.8(0.2)$ & $4.0(0.1)$ \\
\hline Total C, g $100 \mathrm{~g}^{-1}$ soil & $1.3(0.1)$ & $1.7(0.0)$ \\
\hline Exchangeable $\mathrm{K}, \mathrm{mg} 100 \mathrm{~g}^{-1}$ soil & $3.4(0.2)$ & $7.0(0.3)$ \\
\hline Total N, g $100 \mathrm{~g}^{-1}$ soil & $0.09(0.01)$ & $0.14(0.0)$ \\
\hline Single point $\mathrm{PSC}^{\mathrm{c}}$, mg P $100 \mathrm{~g}^{-1}$ soil & $23.7(7.0)$ & $35.3(0.9)$ \\
\hline $\mathrm{CEC}^{\mathrm{de}}, \mathrm{mmol}_{\mathrm{c}} \mathrm{kg}^{-1}$ & 60.7 & 93.2 \\
\hline Base saturation $^{\mathrm{e}}, \mathrm{kg} 100 \mathrm{~kg}^{-1}$ & 61.6 & 77.0 \\
\hline
\end{tabular}

${ }^{a}$ Defined as the amount of water remaining in the pot after full irrigation and visible drainage has ceased (24-48 h of drainage) as described by Kirkham (2004)

${ }^{\mathrm{b}}$ After Banderis et al. (1976) described in Sørensen and Bülow-Olsen (1994)

${ }^{\mathrm{c}}$ PSC, Phosphorus sorption capacity after Bache and Williams (1971)

${ }^{\mathrm{d}} \mathrm{CEC}$, cation exchange capacity

e After Kalra and Maynard (1991) 
Table 3 The effect of slurry acidification on water-extractable reactive $\mathrm{P}\left(\mathrm{WEP}_{\mathrm{i}}\right)$, water-extractable unreactive $\mathrm{P}\left(\mathrm{WEP}_{\mathrm{u}}\right)$, total water-extractable $\mathrm{P}\left(\mathrm{WEP}_{\mathrm{t}}\right)$, ammonium- $\mathrm{N}\left(\mathrm{NH}_{4}{ }^{+}-\mathrm{N}\right)$, N-total,

\begin{tabular}{llllllllll}
\hline Acidification level & DM \% & $\begin{array}{l}\text { Total } \mathrm{P}^{*} \\
\mathrm{~g} \mathrm{~kg}^{-1} \text { dry }\end{array}$ & $\begin{array}{c}\mathrm{WEP}_{\mathrm{i}} \\
\text { weight slurry }\end{array}$ & $\mathrm{WEP}_{\mathrm{u}}$ & $\mathrm{WEP}_{\mathrm{t}}$ & $\mathrm{NH}_{4}{ }^{+}-\mathrm{N}$ & Total N & $\mathrm{Ca}$ & $\mathrm{Mg}$ \\
\hline Strong (pH 3.8) & 11.8 & 7.13 & $4.51^{\mathrm{b}}$ & $0.37^{\mathrm{a}}$ & $4.89^{\mathrm{b}}$ & $14.7^{\mathrm{b}}$ & $35.9^{\mathrm{b}}$ & $6.94^{\mathrm{a}}$ & $4.58^{\mathrm{a}}$ \\
Moderate (pH 5.5) & 11.3 & 7.13 & $4.92^{\mathrm{a}}$ & $0.40^{\mathrm{a}}$ & $5.32^{\mathrm{a}}$ & $16.2^{\mathrm{a}}$ & $38.8^{\mathrm{a}}$ & $4.70^{\mathrm{b}}$ & $4.37^{\mathrm{b}}$ \\
Untreated (pH 6.5) & 11.1 & 7.13 & $2.25^{\mathrm{c}}$ & $0.40^{\mathrm{a}}$ & $2.65^{\mathrm{c}}$ & $16.6^{\mathrm{a}}$ & $39.7^{\mathrm{a}}$ & $2.61^{\mathrm{c}}$ & $2.17^{\mathrm{c}}$ \\
\hline
\end{tabular}

* Measured before acidification

harvest. Occasional weeds were handpicked. Pest control was not required.

Plant and soil sampling

Entire pots with three plants were sampled destructively 45, 60 and 75 DAS corresponding to the five-leaf stage, six-leaf stage and seven-leaf stage, respectively. The plants were cut $1 \mathrm{~cm}$ above the soil surface and ovendried $\left(60^{\circ} \mathrm{C}\right)$ to constant weight for determination of DM weights. The dried plant samples were ground to pass a 1 -mm screen.

At each harvest, soil was sampled in the 0P, 20P, $\mathrm{pH}$ 5.5ENB, pH 6.5ENB, pH 5.5LNB and pH 6.5LNB treatments with a special sampling design, where samples originated from well-defined distances from the narrow fertilizer band. Soil was sampled from two different positions from the fertilizer band, but at the same depth: One soil sample below the narrow fertilizer band, and one soil sample at $5 \mathrm{~cm}$ horizontal distance from the narrow fertilizer band and $8 \mathrm{~cm}$ below the maize seed (Fig. 1). From each position a $25-\mathrm{mm}$ diameter soil core was taken horizontally along the whole pot length $(25 \mathrm{~cm})$.

Analytical methods

Dissolved $\mathrm{P}, \mathrm{Mg}$ and $\mathrm{Ca}$ in slurry were defined in this work as $\mathrm{P}, \mathrm{Mg}$ and $\mathrm{Ca}$ present in the supernatant after dissolved $\mathrm{Ca}$ and $\mathrm{Mg}$ in slurry. Different letters within columns denote statistical significance (Tukey, $P<0.05$ ) centrifugation of the slurry for $30 \mathrm{~min}$ at $20{ }^{\circ} \mathrm{C}$ with a relative centrifugal force $(\mathrm{RCF})$ of $15,029 \mathrm{x} \mathrm{g}$. Dissolved, reactive water-extractable $\mathrm{P}\left(\mathrm{WEP}_{\mathrm{i}}\right)$ and total waterextractable $\mathrm{P}\left(\mathrm{WEP}_{\mathrm{t}}\right)$ in the cattle slurry were measured in the supernatant after extractions of $3 \mathrm{~g}$ slurry (fresh weight) shaken with $30 \mathrm{ml}$ of deionized water for $1 \mathrm{~h}$ at $20{ }^{\circ} \mathrm{C}$ followed by centrifugation as described above. $\mathrm{WEP}_{\mathrm{i}}$ concentrations were determined by spectrophotometry on the centrifuged sample using the molybdic blue method (ISO 6878 2004) modified after Murphy and Riley (1962). $\mathrm{WEP}_{\mathrm{t}}$ in the slurry was determined in a subsample of the supernatant using acid persulfate digestion in an autoclave $\left(120^{\circ} \mathrm{C}, 200 \mathrm{kPa}\right)$ (Koroleff 1983) followed by measurement of $\mathrm{WEP}_{\mathrm{t}}$ concentrations with the colorimetric method described above. The concentration of dissolved $\mathrm{Mg}^{2+}$ and $\mathrm{Ca}^{2+}$ in the supernatant was measured using atom absorption spectroscopy. Slurry $\mathrm{DM}$ was determined by drying for $24 \mathrm{~h}$ at $80^{\circ} \mathrm{C}$. Total ammonium-N was measured by flow colorimetry (Sommer et al. 1992) and total $\mathrm{N}$ in slurry was analyzed using a Kjeldahl method. Total $\mathrm{P}$ in slurry was determined after digestion in perchloric and sulfuric acid (ISO 6878 2004).

Ammonium-N $\left(\mathrm{NH}_{4}{ }^{+}-\mathrm{N}\right)$ and nitrate- $\mathrm{N}\left(\mathrm{NO}_{3}{ }^{-} \mathrm{N}\right)$ in soil were determined by flow colorimetry (Autoanalyzer III, Bran + Luebbe GmbH, D 22803 Nordersted, Germany) after extracting fresh soil immediately after sampling with $2 \mathrm{M} \mathrm{KCl}$ by shaking for $1 \mathrm{~h}(1: 4, w / \mathrm{w})$. After extraction the soil was oven-dried for $24 \mathrm{~h}$ at $105^{\circ} \mathrm{C}$
Fig. 1 Cross-sectional view of the pot (left and centre). The pot seen from above (right) in the narrow band $(\mathrm{NB})$ treatments
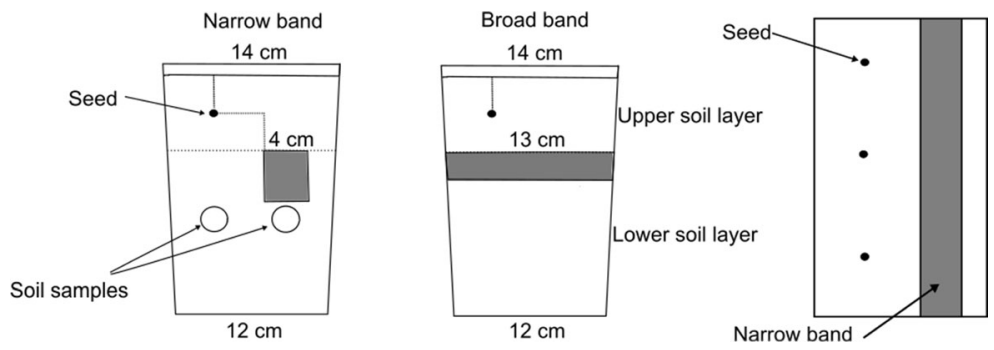
for dry weight determination. Soil samples for $\mathrm{pH}$ determination and $\mathrm{P}$ analyses were air-dried and sieved (2-mm sieve). Soil $\mathrm{pH}$ was measured in water suspensions (1:2.5, $w / \mathrm{w}) . \mathrm{WEP}_{\mathrm{i}}$ and $\mathrm{WEP}_{\mathrm{t}}$ in soil were measured in the supernatant after extraction of $1 \mathrm{~g}$ of air-dried soil shaken in $50 \mathrm{ml}$ of deionized water for $1 \mathrm{~h}$ at $20^{\circ} \mathrm{C}$ followed by centrifugation for $10 \mathrm{~min}$ at $20^{\circ} \mathrm{C}$ with RCF at $1831 \mathrm{x} g$. Concentrations of $\mathrm{WEP}_{\mathrm{i}}$ and $\mathrm{WEP}_{\mathrm{t}}$ in soil extracts were determined as described for manure above.

The $\mathrm{P}$ concentration in plant tissue was determined by digesting $300 \mathrm{mg}$ dried plant material in $3 \mathrm{ml} \mathrm{H}_{2} \mathrm{O}_{2}$ $(9.7 \mathrm{M})$ and $6 \mathrm{ml} \mathrm{HNO}_{3}(14.3 \mathrm{M})$ by pressurized microwave digestion. The $\mathrm{P}$ concentration in the diluted digest was determined by ICP-OES according to Liu et al. (2013).

Data calculation and statistical analysis

The fraction of unreactive water-extractable $\mathrm{P}\left(\mathrm{WEP}_{\mathrm{u}}\right)$ was determined as the difference between $\mathrm{WEP}_{\mathrm{t}}$ and $\mathrm{WEP}_{\mathrm{i}}$. Total inorganic $\mathrm{N}$ (Nmin) in soil was calculated as the sum of $\mathrm{NO}_{3}{ }^{-}-\mathrm{N}$ and $\mathrm{NH}_{4}{ }^{+}-\mathrm{N}$. Total $\mathrm{P}$ uptake (PU) was calculated from dry matter weights and the $\mathrm{P}$ concentration of the whole plant.

The statistical analysis was conducted using the RProject software package Version 3.2.3 (R Development Core Team 2015). Linear models were applied for the dependent variables P concentration, DM yield and PU. The ordinary least square approach was used for estimating the parameters in the linear models. In cases where the treatment effect was found to be significant in a one-way analysis of variance (ANOVA), further analyses were made to isolate differences between treatments (pairwise comparisons) using the general linear hypotheses $(g l h t)$ function implemented in the multcomp package in $\mathrm{R}$. The treatment effect was split up into the three factors (acidification, application technique and application time) and their interactions to identify significant predictors by performing a threeway ANOVA (type II) implemented in the car package in R. Direct comparisons of balanced grouped treatments were done by orthogonal main effects contrast statements by calculating the differences in LS means between levels of a significant factor implemented in the contrast package in R. DM yield at 75 DAS on the sandy loam, P concentration at 45 DAS on the sandy loam and PU at 60 DAS on the sandy soil were logtransformed to obtain normal distribution of residuals. Relationships between continuous variables were examined by calculating Pearson's correlation coefficient (r). Significance was declared at the $P \leq 0.05$ level of probability if nothing else is stated.

\section{Results}

Acidification effects on cattle slurry composition

The concentration of $\mathrm{WEP}_{\mathrm{i}}$ and $\mathrm{WEP}_{\mathrm{t}}$ was significantly higher in the moderately acidified slurry ( $\mathrm{pH} 5.5$ ), whereas the untreated slurry had the lowest concentration of $\mathrm{WEP}_{\mathrm{i}}$ and $\mathrm{WEP}_{\mathrm{t}}$ (Table 3). Contrastingly, the concentration of $\mathrm{WEP}_{\mathrm{u}}$ was not affected by the acidification. $\mathrm{WEP}_{\mathrm{i}}$ represented 32, 69 and $62 \%$ of the total $\mathrm{P}$ in slurry in untreated, moderately acidified ( $\mathrm{pH} 5.5)$ and strongly acidified slurry ( $\mathrm{pH} 3.8$ ), respectively. The concentrations of water-extractable $\mathrm{Ca}$ and $\mathrm{Mg}$ were highest in the strongly acidified slurry and lowest in the untreated slurry (Table 3).

$\mathrm{P}$ concentrations in maize tissue

On both soils the $\mathrm{P}$ concentration in maize tissue was significantly higher 45 DAS in 20P compared to $0 \mathrm{P}$ treatments (Fig. 2). Injection of slurry in a broad band led to $\mathrm{P}$ concentrations at $45 \mathrm{DAS}$ similar to the $20 \mathrm{P}$ treatment on both soils. The $\mathrm{P}$ concentration in maize tissue decreased drastically from 45 DAS to 60 DAS. The $P$ concentration did not differ among the treatments at 60 and 75 DAS, except on the sandy soil 75 DAS, where $20 \mathrm{P}$ had a significantly higher $\mathrm{P}$ concentration compared to 0P. A significant correlation was found between the maize P concentration 45 DAS and DM yield 75 DAS $(r=0.69, P<0.01)$ on the sandy loam, whereas no significant correlations were found between maize P concentration 60 or 75 DAS and DM yield 75 DAS.

DM yield

On both soils, the response of mineral P fertilizer (20P) on DM yield was positive compared to the $0 \mathrm{P}$ treatment, but only significant at 75 DAS on the coarse sandy soil (Fig. 3). On the coarse sandy soil, all treatments receiving slurry as starter fertilizer had a DM yield equal to or higher than the 20P treatment at 75 DAS. Treatments with strongly acidified slurry $(\mathrm{pH} 3.8$ ) resulted in DM yields higher than the 20P treatment (on average 16\%) 


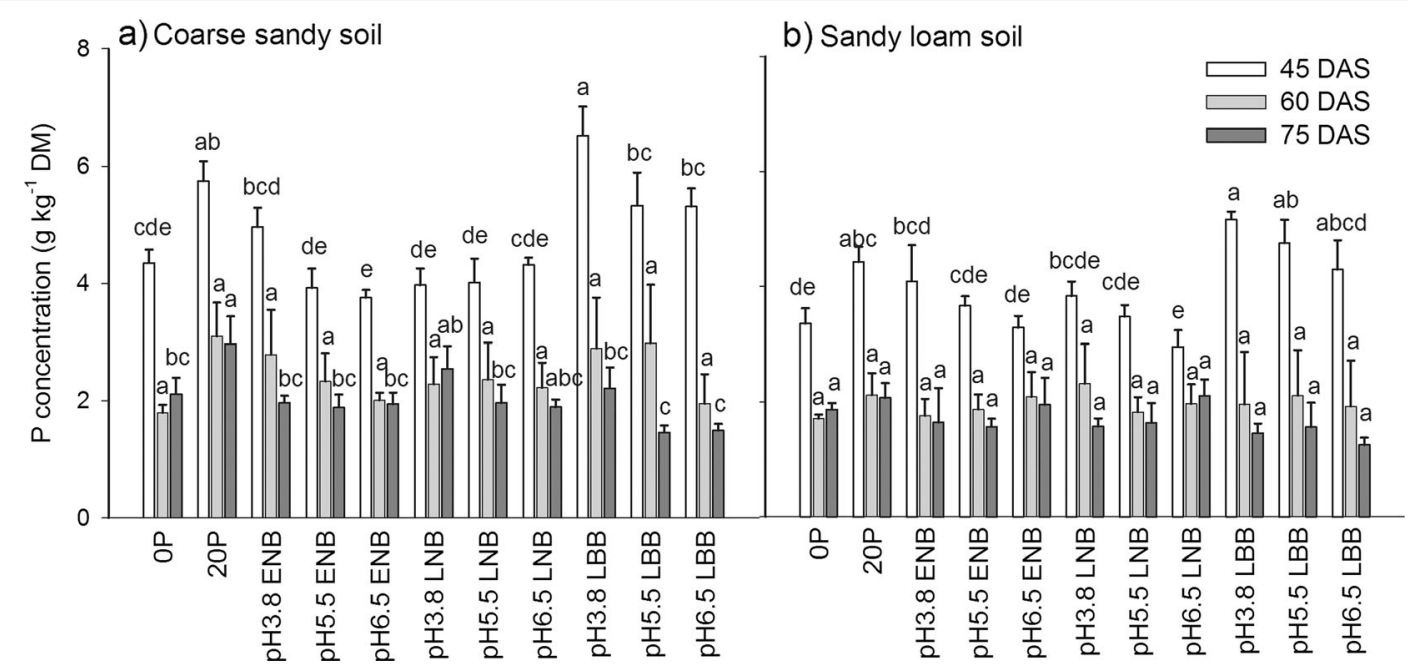

Fig. $2 \mathrm{P}$ concentration $\left(\mathrm{g} \mathrm{kg}^{-1} \mathrm{DM}\right)$ in whole maize plants for the different fertilizer and manure treatments on a) coarse sandy soil and b) sandy loam. DAS: Days after sowing (45: five-leaf stage; 60: six-leaf stage; 75: seven-leaf stage). Different letters denote

in this soil, irrespective of the application time and technique. Remarkably high (on average $40 \%$ higher than 20P) DM yield was observed 75 DAS on the coarse sandy soil, when the slurry was injected in a broad band, irrespective of the acidification level. Similarly, a significant increase in DM yield compared to the OP treatment was observed at 75 DAS when the slurry was injected in a broad band on the sandy loam. Injection significant differences between treatments within each harvest time (Tukey, $P<0.05$ ). Error bars represent the standard deviation $(n=3)$. For treatment abbreviations see Table 1

of untreated slurry in a narrow band 30 days before sowing ( $\mathrm{pH}$ 6.5 ENB) in the sandy loam, did not result in an increased DM yield compared to $0 \mathrm{P}$.

On both soils, the DM yield 75 DAS was significantly higher in treatments receiving strongly acidified slurry compared to treatments with untreated slurry when the slurry was applied 30 days before sowing in a narrow band, whereas these differences were not

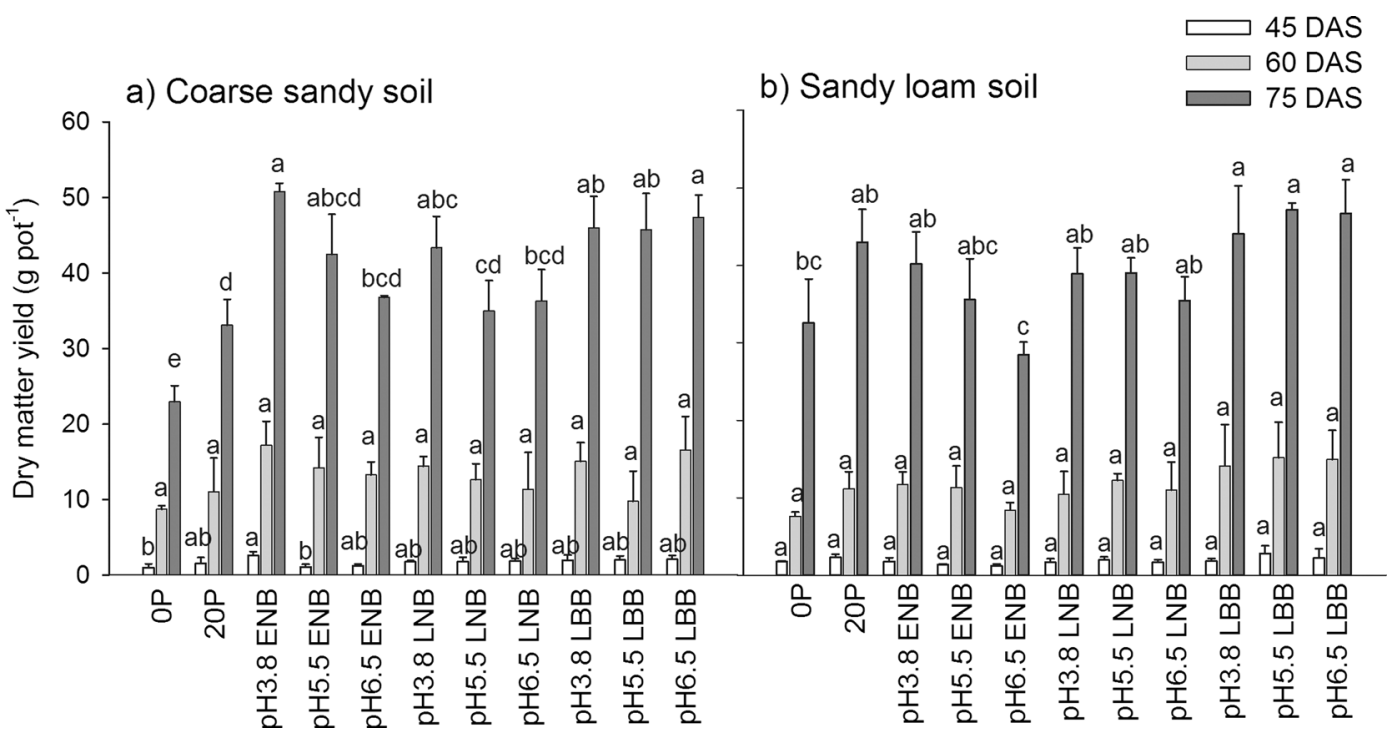

Fig. 3 Dry matter yields (g pot ${ }^{-1}$ ) for the different fertilizer and manure treatments on a) the coarse sandy soil and b) the sandy loam. DAS: Days after sowing (45: five-leaf stage; 60: six-leaf stage; 75: seven-leaf stage). Different letters denote significant differences

between treatments within each harvest time (Tukey, $P<0.05$ ). Error bars represent the standard deviations $(n=3)$. For treatment abbreviations see Table 1 
Table 4 Total $\mathrm{P}$ uptake in maize plants measured 45, 60 and 75 days after sowing (DAS) (45: five-leaf stage; 60: six-leaf stage; 75: seven-leaf stage) and selected pot treatment contrasts.

\begin{tabular}{|c|c|c|c|c|c|c|c|}
\hline \multirow[t]{3}{*}{ Treatment } & \multirow[t]{3}{*}{ Treatment abbrevation } & \multicolumn{6}{|c|}{$\mathrm{P}$ uptake (mg P pot $\left.{ }^{-1}\right)$} \\
\hline & & \multicolumn{3}{|c|}{ Coarse sandy soil } & \multicolumn{3}{|c|}{ Sandy loam } \\
\hline & & 45 & 60 & 75 & 45 & 60 & 75 \\
\hline 1 & $0 \mathrm{P}$ & $4.4^{\mathrm{b}}$ & $15.6^{\mathrm{c}}$ & $48.2^{\mathrm{c}}$ & $5.9^{\mathrm{ab}}$ & $13.1^{\mathrm{c}}$ & $60.5^{\mathrm{a}}$ \\
\hline 2 & $20 \mathrm{P}$ & $9.0^{\mathrm{ab}}$ & $32.5^{\mathrm{ab}}$ & $98.4^{\mathrm{ab}}$ & $10.1^{\mathrm{ab}}$ & $23.2^{\mathrm{abc}}$ & $88.2^{\mathrm{a}}$ \\
\hline 3 & pH 3.8 ENB & $12.9^{\mathrm{a}}$ & $47.0^{\mathrm{a}}$ & $100.1^{\mathrm{ab}}$ & $7.2^{\mathrm{ab}}$ & $20.4^{\mathrm{abc}}$ & $66.8^{\mathrm{a}}$ \\
\hline 4 & pH 5.5 ENB & $4.0^{\mathrm{b}}$ & $32.1^{\mathrm{ab}}$ & $79.4^{\mathrm{abc}}$ & $5.0^{\mathrm{b}}$ & $21.1^{\mathrm{abc}}$ & $55.5^{\mathrm{a}}$ \\
\hline 5 & $\mathrm{pH} 6.5 \mathrm{ENB}$ & $4.3^{\mathrm{b}}$ & $26.7^{\mathrm{abc}}$ & $71.4^{\mathrm{bc}}$ & $4.1^{\mathrm{b}}$ & $17.3^{\mathrm{bc}}$ & $55.8^{\mathrm{a}}$ \\
\hline 6 & pH 3.8 LNB & $6.9^{\mathrm{ab}}$ & $33.3^{\mathrm{ab}}$ & $111.3^{\mathrm{a}}$ & $6.3^{\mathrm{ab}}$ & $23.0^{\mathrm{abc}}$ & $61.1^{\mathrm{a}}$ \\
\hline 7 & $\mathrm{pH} 5.5$ LNB & $7.2^{\mathrm{ab}}$ & $28.9^{\mathrm{abc}}$ & $68.0^{\mathrm{bc}}$ & $6.8^{\mathrm{ab}}$ & $22.4^{\mathrm{abc}}$ & $63.6^{\mathrm{a}}$ \\
\hline 8 & $\mathrm{pH} 6.5 \mathrm{LNB}$ & $7.9^{\mathrm{ab}}$ & $23.9^{\mathrm{bc}}$ & $68.4^{\mathrm{bc}}$ & $4.9^{\mathrm{b}}$ & $20.8^{\mathrm{abc}}$ & $75.2^{\mathrm{a}}$ \\
\hline 9 & pH 3.8 LBB & $13.0^{\mathrm{a}}$ & $42.6^{\mathrm{ab}}$ & $102.6^{\mathrm{ab}}$ & $8.8^{\mathrm{aa}}$ & $24.9^{\mathrm{ab}}$ & $65.0^{\mathrm{a}}$ \\
\hline 10 & $\mathrm{pH} 5.5 \mathrm{LBB}$ & $10.5^{\mathrm{ab}}$ & $27.0^{\mathrm{abc}}$ & $67.2^{\mathrm{bc}}$ & $13.0^{\mathrm{a}}$ & $29.8^{\mathrm{a}}$ & $73.6^{\mathrm{a}}$ \\
\hline 11 & $\mathrm{pH} 6.5$ LBB & $11.0^{\mathrm{ab}}$ & $31.1^{\mathrm{ab}}$ & $70.5^{\mathrm{bc}}$ & $9.5^{\mathrm{ab}}$ & $28.1^{\mathrm{ab}}$ & $58.9^{\mathrm{a}}$ \\
\hline \multicolumn{8}{|l|}{ Pot treatment contrasts } \\
\hline \multicolumn{8}{|c|}{ Acidification differences } \\
\hline A) $3,6,9$ vs. $4,7,10$ & pH 3.8 vs. pH 5.5 & $3.7^{\mathrm{ns}}$ & $11.6^{*}$ & $33.1^{*}$ & $-0.8^{\mathrm{ns}}$ & $-1.6^{\mathrm{ns}}$ & $0.1^{\mathrm{ns}}$ \\
\hline B) $3,6,9$ vs. $5,8,11$ & pH 3.8 vs. pH 6.5 & $3.2^{\mathrm{ns}}$ & $13.7^{*}$ & $34.6^{*}$ & $1.3^{\mathrm{ns}}$ & $0.7^{\mathrm{ns}}$ & $1.0^{\mathrm{ns}}$ \\
\hline C) $4,7,10$ vs. $5,8,11$ & pH 5.5 vs. pH 6.5 & $-0.5^{\mathrm{ns}}$ & $2.1^{\mathrm{ns}}$ & $1.4^{\mathrm{ns}}$ & $2.1^{\mathrm{ns}}$ & $2.4^{\mathrm{ns}}$ & $1.0^{\mathrm{ns}}$ \\
\hline \multicolumn{8}{|c|}{ Application time differences } \\
\hline D) $3,4,5$ vs. $6,7,8$ & Early (E) vs. late (L) & $-0.3^{\mathrm{ns}}$ & $6.6^{\mathrm{ns}}$ & $1.1^{\mathrm{ns}}$ & $-0.6^{\mathrm{ns}}$ & $-2.5^{\mathrm{ns}}$ & $-7.3^{\mathrm{ns}}$ \\
\hline \multicolumn{8}{|c|}{ Application technique differences } \\
\hline E) $6,7,8$ vs. $9,10,11$ & Narrow band (NB) vs. broad band (BB) & $-4.2^{*}$ & $-4.9^{\mathrm{ns}}$ & $2.5^{\mathrm{ns}}$ & $-4.6^{* *}$ & $-5.5^{*}$ & $0.8^{\mathrm{ns}}$ \\
\hline
\end{tabular}

Different letters within columns denote statistical significance among treatments (Tukey, $P<0.05$ ). For treatment abbreviations . . 
practices in Denmark. Soil from both the application times was sampled in order to demonstrate changes over time.

On the coarse sandy soil, the soil $\mathrm{pH}$ ranged from 4.5 to 7.0 below the band and from 4.6 to 6.1 distant from the band (Fig. 4a). On the sandy loam $\mathrm{pH}$ had a range of 5.4 to 6.9 compared to a soil $\mathrm{pH}$ range of 5.9 to 6.4 distant from the band (Fig. 4b). On both soils, the soil $\mathrm{pH}$ in the untreated slurry treatments $\mathrm{pH}$ 6.5 ENB and $\mathrm{pH} 6.5 \mathrm{LNB}$ ) below the band was similar to or higher than the initial soil $\mathrm{pH}$, while the moderately acidified slurry decreased soil $\mathrm{pH}$ below the band. The $0 \mathrm{P}$ and 20P treatments on the coarse sandy soil had the lowest soil $\mathrm{pH}$ both below and distant from the band (Fig. 4).

On the coarse sandy soil, early application of moderately acidified slurry (pH 5.5 ENB) resulted in a significantly higher concentration of $\mathrm{WEP}_{\mathrm{i}}$ and $\mathrm{WEP}_{\mathrm{u}}$ in the soil below the band than with all the other treatments at 45 DAS (Fig. 5a). At 75 DAS the highest concentration of $\mathrm{WEP}_{\mathrm{i}}$ below the band was found with the late application of moderately acidified slurry ( $\mathrm{pH} 5.5 \mathrm{LNB}$ ). The numerical differences of WEP for the treatments within each harvest time distant from the band were small for both soils (Fig. 5). To study the mobility of $\mathrm{P}$ and $\mathrm{N}$ in soil from 45 DAS to 75 DAS, correlation coefficients were calculated. The correlation between the $\mathrm{WEP}_{\mathrm{i}}$ measurements below and distant from the slurry band was insignificant on both the sandy soil $(r=0.14$, $P=0.38)$ and the sandy loam $(r=0.00, P=0.99)$, and likewise for $\mathrm{WEP}_{\mathrm{u}}$ with the slurry treatments on the sandy soil $(r=0.23, P=0.17)$, whereas a significant correlation was found between $\mathrm{WEP}_{\mathrm{u}}$ below the band and $\mathrm{WEP}_{\mathrm{u}}$ distant from the band for the slurry treatments on the sandy loam $(r=0.59, P<0.001)$.

At 60 DAS and 75 DAS Nmin decreased rapidly on both soils (Fig. 6). There was a strong linear relationship between $\mathrm{NO}_{3}{ }^{-}-\mathrm{N}$ in the soil below and distant from the band for the slurry treatments on both the coarse sandy soil $(r=0.96, P<0.001)$ and the sandy loam $(r=0.94$, $P<0.001)$, whereas there were no significant correlations between $\mathrm{NH}_{4}{ }^{+} \mathrm{-N}$ below and distant from the band on either the coarse sandy soil $(r=0.09, P=0.61)$ or the sandy loam $(r=-0.27, P=0.11)$.

\section{Discussion}

\section{Effects of application technique}

At the first plant sampling $\mathrm{P}$ concentrations were significantly higher in the 20P treatment compared to $0 \mathrm{P}$ on both soils. The positive effect of the 20P treatment was later on reflected in significantly higher DM yields and PU at 75 DAS on the sandy soil and this tendency was also seen on the sandy loam. This underlines the importance for maize growth of exposing the roots to sufficient exogenous $\mathrm{P}$ while plants are young and the root surface area limited.

Treatments receiving slurry in a broad band had significantly higher DM yields compared to the OP treatment on both soils at 75 DAS irrespective of the acidification level. On the sandy soil the final DM yield

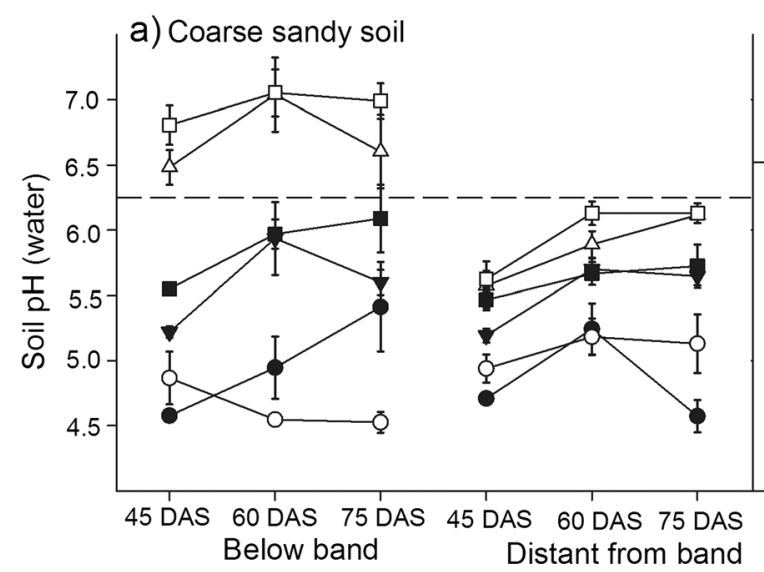

b) Sandy loam soil

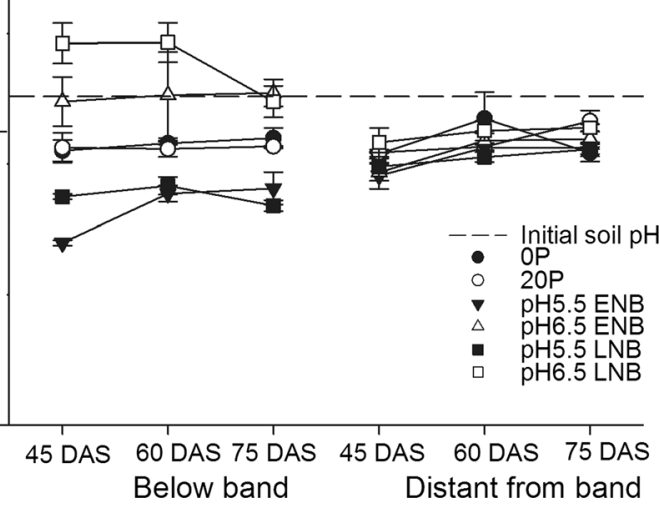

Fig. 4 Soil pH (water) measured 45, 60 and 75 DAS after amendment of mineral fertilizer and cattle slurry to a) the coarse sandy soil and b) the sandy loam. Distant from band: Soil sampled $5 \mathrm{~cm}$ distant (horizontally) from the narrow fertilizer band. Below band:

Soil sampled below the narrow fertilizer band. DAS: Days after sowing (45: five-leaf stage; 60: six-leaf stage; 75: seven-leaf stage). Error bars represent the standard error of the mean $(n=3)$. For treatment abbreviations see Table 1 


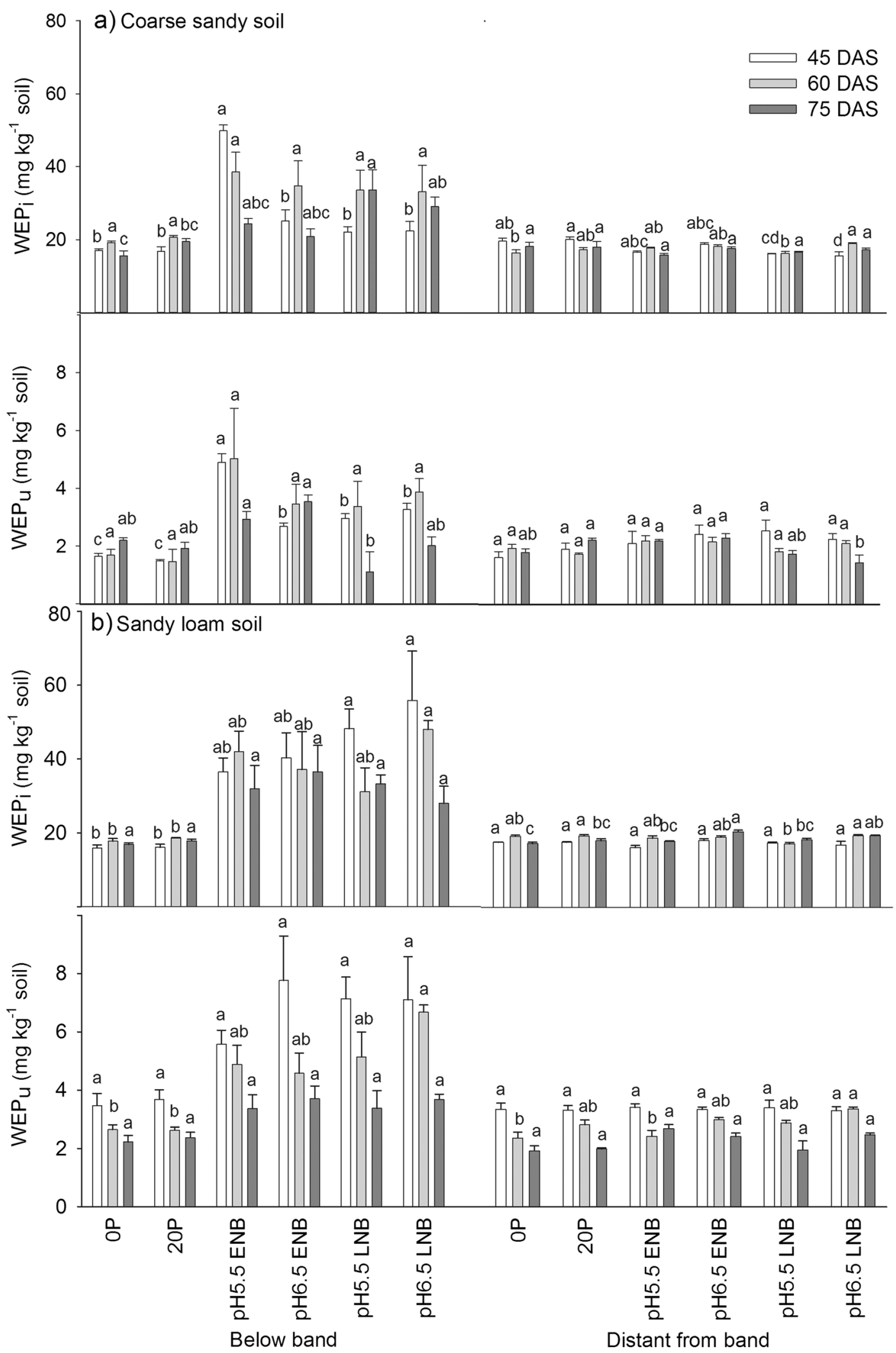


Fig. 5 Water-extractable reactive $P\left(W P_{i}\right)$ and unreactive $P$ $\left(\mathrm{WEP}_{\mathrm{u}}\right)$ in soil after amendment of mineral fertilizer and cattle slurry to a) the coarse sandy soil and b) the sandy loam. Below band: Soil sampled below the narrow fertilizer band. Distant from band: Soil sampled $5 \mathrm{~cm}$ distant (horizontally) from the narrow fertilizer band. DAS: Days after sowing (45: five-leaf stage; 60 : six-leaf stage; 75: seven-leaf stage). Different letters denote significant differences between treatments within each harvest time (Tukey, $P<0.05)$. Error bars represent the standard error of the mean $(n=3)$. For treatment abbreviations see Table 1

was even higher with broad-banded slurry than in the 20P treatment, indicating that the higher DM yield was not only a result of higher $P$ availability, but also related to other growth promoting effects of the slurry such as higher availability of other nutrients in the broad-banded slurry. On both soils broad-banded slurry treatments had $P$ concentrations in maize tissue at 45 DAS similar to the 20P treatment (Fig. 2). Moreover, the strong correlation between $\mathrm{P}$ concentration at 45 DAS and DM yield at 75DAS on the sandy loam implies that the maize plants were able to benefit from slurry $\mathrm{P}$ applied in a broad band. The lack of a response in the P concentrations 60 and 75 DAS could be due to a proportional increment in DM yield, as also pointed out by Schröder et al. (2015). The beneficial effect of the broad band injection could be due to: a) The broad band being placed closer to the seed both horizontally and vertically than the narrow band giving plants quicker access to $\mathrm{N}$ and $\mathrm{P}, \mathrm{b}$ ) in the narrow band unfavorable conditions for root growth persisted for a longer period (Sawyer and Hoeft 1990), limiting root access to $\mathrm{P}$, and c) maize plants were forced to grow through the layer of broad-banded slurry resulting in fast access to nutrients.

The lack of a relationship between $\mathrm{WEP}_{\mathrm{i}}$ below and distant from the narrow band clearly demonstrated the limited mobility of $\mathrm{WEP}_{\mathrm{i}}$ in the soil, whereas the opposite was observed for $\mathrm{NO}_{3}{ }^{-}-\mathrm{N}$, which moved readily with soil water by mass flow and by diffusion. This confirms the rationale for placing the exogenous $\mathrm{P}$ pool close to the seed and preferably in a broad band, which may ensure quicker access to the manure nutrients and enlarge the root surface area exposed to slurry P compared to the narrow band. These findings support explanation a) and c) above.

We interpret the significant correlation between $\mathrm{WEP}_{\mathrm{u}}$ below and distant from the band on the sandy loam as an indication that $\mathrm{WEP}_{\mathrm{u}}$ is more mobile than $\mathrm{WEP}_{\mathrm{i}}$, and to some degree resembles the mobility of $\mathrm{NO}_{3}{ }^{-}{ }^{-} \mathrm{N}$. Glaesner et al. (2011) also demonstrated increased mobility of some forms of organic P compared to inorganic $\mathrm{P}$ in a leaching study. Magid et al. (1996) suggested that organic P compounds might be held less strongly by the soil matrix, because $\mathrm{P}$ bound to or in organic matter may be masked from potential sorption sites. $\mathrm{WEP}_{\mathrm{u}}$ is prone to mineralization and could potentially be measured as $\mathrm{WEP}_{\mathrm{i}}$ after mineralization, but, unfortunately, it was not possible to determine which role $\mathrm{WEP}_{\mathrm{u}}$ played for PU in the present study.

Mineral $\mathrm{P}$ fertilizer application mimicked the placement of slurry in the narrow band, but the 20P treatment had higher plant $\mathrm{P}$ concentrations similar to the broadbanded slurry treatments (Fig. 2). The lower P concentrations in treatments with narrow-band slurry injection could be due to unfavorable conditions in the concentrated narrow band with possible salt stress or anaerobic conditions and formation of organic acids, as described by Sawyer and Hoeft (1990) and Lynch (1980) and suggested in explanation b). Whether the higher DM yields in treatments with slurry applied in a broad band only is the result of higher availability of $\mathrm{P}$ is questionable. The better growth response at 75 DAS could also be due to a general improvement of nutrient availability in the broad band, as suggested in explanations a) and c). Nmin decreased rapidly from 45 to 75 DAS in slurry treatments, and we cannot exclude that the maize plants were N-limited at 75 DAS. However, DM yield increased significantly from 60 DAS to 75 DAS and the soils still contained inorganic $\mathrm{N}$ at $60 \mathrm{DAS}$, indicating that inorganic $\mathrm{N}$ could only have been the limiting factor in a short part of the growth period between 60 and 75 DAS. Moreover, we did not observe visible $\mathrm{N}$ deficiency symptoms on the plants. The mean Nmin concentration in soil was highest in the treatment with $\mathrm{N}$ fertilizer alone (0P) at 75 DAS in the sandy soil (Fig. 6). This could be explained by the poor plant growth, and hence a lower $\mathrm{N}$ uptake by maize.

It is concluded that the maize planted above a broad slurry band benefited from the quick and improved access to the manure nutrients, including P. The improved growth response with broad-banded slurry applications could also be due to less toxic conditions to root growth compared to the narrow slurry band. However, the improved effect of broad banding could also be a result of reduced distance to the seed in the broad band treatments compared to the narrow band. A narrow slurry band placed just below the seed at similar distance might have given similar results as the broad 

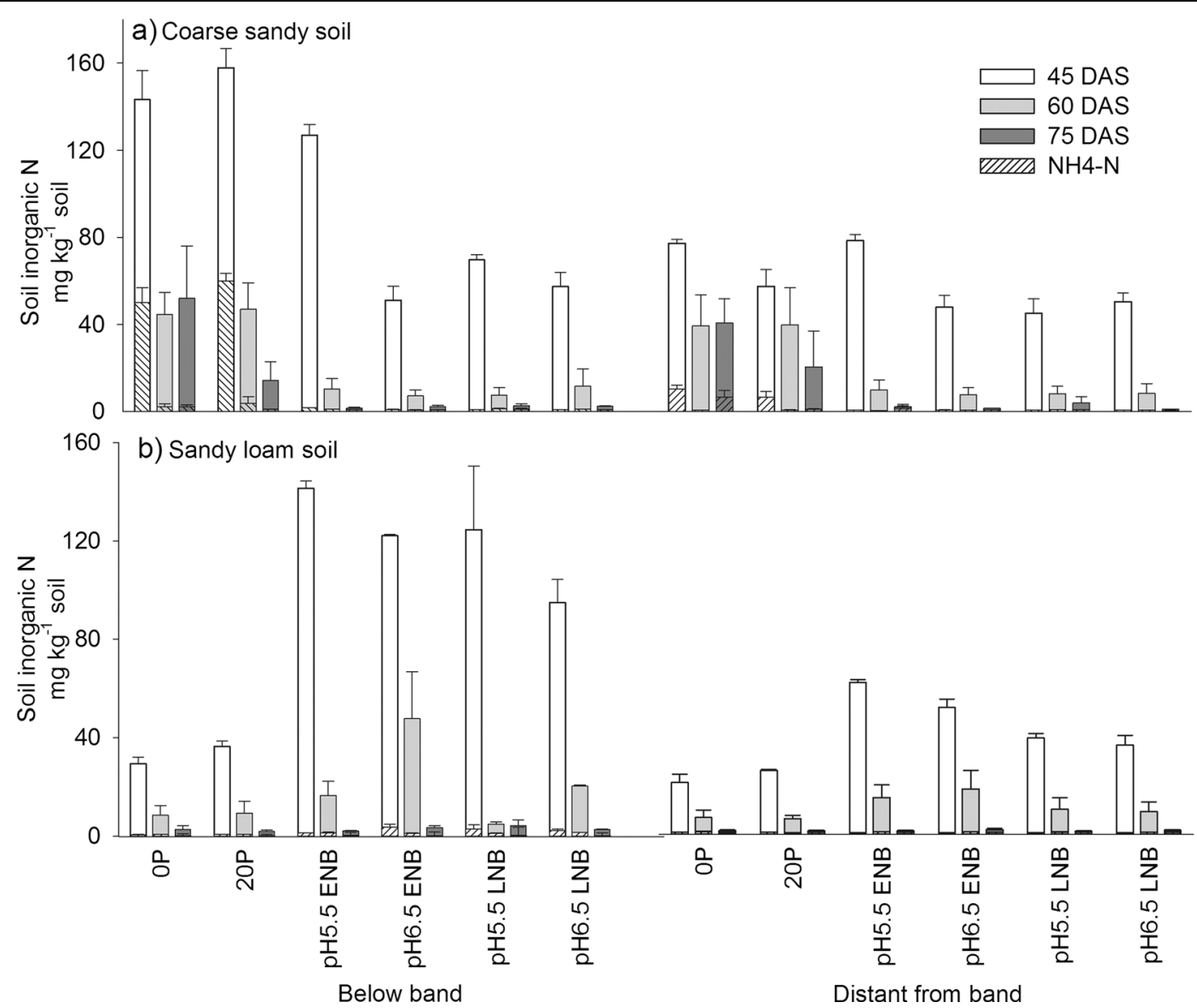

Fig. 6 Soil inorganic $\mathrm{N}$ after amendment of mineral fertilizer and cattle slurry to the a) coarse sandy soil and b) sandy loam. Below band: Soil sampled below the narrow fertilizer band. Distant from band: Soil sampled $5 \mathrm{~cm}$ distant (horizontally) to the narrow

band. To clarify this further studies are needed on slurry band placement, where also growth and spatial distribution of roots are determined.

\section{Effects of slurry acidification}

Moderate $(\mathrm{pH} 5.5)$ and strong slurry acidification $\left(\mathrm{pH} 3.8\right.$ ) increased the concentration of $\mathrm{WEP}_{\mathrm{i}}$ in slurry compared to untreated slurry, whereas the acidification did not have an effect on $\mathrm{WEP}_{\mathrm{u}}$ (Table 3), indicating that the acidification mainly affected the inorganic $\mathrm{P}$ in slurry. By lowering the $\mathrm{pH}$ to 5.5 and 3.8 it was possible to dissolve 76 and $72 \%$ of total $P$ in the slurry, respectively, confirming that acidification can be used to adjust the amount of dissolved $\mathrm{P}$ in slurry. Dissolved $\mathrm{Mg}$ and $\mathrm{Ca}$ increased drastically from $\mathrm{pH} 6.5$ to 5.5 , indicating that struvite $\left(\mathrm{NH}_{4} \mathrm{MgPO}_{4}\right)$ and $\mathrm{P}$ bound to $\mathrm{Ca}$ phosphate minerals are dissolved. Christensen et al. (2009) also fertilizer band. DAS: Days after sowing (45: five-leaf stage; 60 : six-leaf stage; 75: seven-leaf stage). Error bars represent the standard error of the mean $(n=3)$. For treatment abbreviations see Table 1

found an increase in the concentration of dissolved $\mathrm{P}$ in pig slurry by lowering the $\mathrm{pH}$ from 6.3 to 5.5 , and this was mainly attributed to the dissolution of struvite. Fordham and Schwertmann (1977) found that most of the $\mathrm{P}$ dissolved was attributed to Ca phosphate minerals in the $\mathrm{pH}$ range from 6.7 to 5.5, whereas no additional $\mathrm{P}$ was dissolved when $\mathrm{pH}$ dropped below 5.5, which is in line with our results.

On the sandy soil, PU was significantly higher 60 and 75 DAS, when the slurry was strongly acidified ( $\mathrm{pH} 3.8)$ compared to moderately acidified slurry $(\mathrm{pH} 5.5)$ and untreated slurry ( $\mathrm{pH}$ 6.5), whereas no effect of acidification was observed on the sandy loam. The contrasting effect of slurry acidification on PU on the two soils might be explained by their different buffer capacities. Soil $\mathrm{pH}$ below the band was highly affected by the treatments on both soils, but the range of the soil $\mathrm{pH}$ was higher in the sandy soil compared to the sandy loam 
(Fig. 4), which is also reflected in the higher CEC and base saturation of the sandy loam (Table 2), providing a better buffer against soil acidification. The lacking effect of acidification on the sandy loam with respect to PU could also be due to the significantly higher P sorption capacity (PSC) of the sandy loam (Table 2), and hence increased capacity to rapidly remove dissolved reactive $\mathrm{P}$ from the soil solution.

Similar PU values in treatments receiving acidified slurry on the sandy soil would be expected, since the numerical difference in slurry $\mathrm{WEP}_{\mathrm{i}}$ between the two acidification levels was small. However, a significantly higher PU was observed in treatments receiving strongly acidified slurry compared to moderately acidified slurry on the sandy soil. We did not measure the $\mathrm{pH}$ in soil amended with strongly acidified slurry, but expect that soil $\mathrm{pH}$ would be lower than the $\mathrm{pH}$ in soil amended with moderately acidified slurry and that a lower soil $\mathrm{pH}$ level will be maintained for a longer period compared to the soil $\mathrm{pH}$ in treatments with moderately acidified slurry that slightly increased from 45 to 75 DAS on the sandy soil (Fig. 4). Soil $\mathrm{pH}$ distant from the band decreased compared to the initial soil $\mathrm{pH}$, not only for slurry-amended soils, but also for the mineral fertilizer treatments $(0 \mathrm{P}$ and $20 \mathrm{P})$. Hence, the decrease in soil $\mathrm{pH}$ could not be attributed solely to the application of acidified slurry, but also to mineralization of $\mathrm{N}$ and nitrification during the experiment. On the sandy soil the $0 \mathrm{P}$ and 20P treatments had the lowest soil $\mathrm{pH}$ at all sampling times both below and distant from the fertilizer band. This could be due to the limited inherent capacity of this soil to buffer the acidification arising from nitrification of the added $\mathrm{NH}_{4}{ }^{+}$combined with the absence of buffering slurry compounds (Sommer and Husted 1995), which are expected to be present in the slurry treatments. At the low $\mathrm{pH}$ we observed in this soil sorption of $\mathrm{P}$ with $\mathrm{Fe}$ and $\mathrm{Al}$ containing minerals would be expected (Lindsay et al. 1989), which could reduce the $\mathrm{P}$ availability in the reference treatments on the sandy soil. However, the $\mathrm{P}$ concentration in plant tissues at 45 DAS was significantly higher in the 20P treatment compared to the $0 \mathrm{P}$ treatment, which indicate that the plants were able to take up $\mathrm{P}$ also at this $\mathrm{pH}$ level. Application of untreated slurry to the sandy soil resulted in higher soil $\mathrm{pH} 1$ below the band than both the initial slurry $\mathrm{pH}$ and the initial soil $\mathrm{pH}$. This may be due to oxidation of slurry volatile fatty acids as described by Sørensen (1998) and buffering compounds in slurry (Sommer and Husted 1995) combined with the low inherent buffer capacity of the sandy soil. The highest PU was observed in treatments with strongly acidified slurry on the sandy soil. The expected lower soil $\mathrm{pH}$ induced by the strongly acidified slurry itself and the abovementioned acidifying processes could probably prevent $\mathrm{Ca}$ added with the slurry to precipitate with $\mathrm{P}$ from soil and/or slurry, which could increase the $\mathrm{P}$ availability. Moreover soil $\mathrm{pH}$ also controls the $\mathrm{P}$ speciation (Hinsinger 2001). As soil pH decreases, the concentration of $\mathrm{H}_{2} \mathrm{PO}_{4}{ }^{-}$in the soil solution increases and $\mathrm{H}_{2} \mathrm{PO}_{4}{ }^{-}$is the substrate of the proton-coupled phosphate symporter in the plasma membrane (White 2006). Higher concentration of $\mathrm{H}_{2} \mathrm{PO}_{4}{ }^{-}$might therefore promote a higher $\mathrm{P}$ uptake, explaining the highest $\mathrm{PU}$ in the treatments with strongly acidified slurry.

In conclusion, the concentration of $\mathrm{WEP}_{\mathrm{i}}$ in the slurry increased at both slurry acidification levels, but since the PU was significantly higher in treatments with strongly acidified slurry compared to moderately acidified slurry on the sandy soil, the increase of PU was probably not solely due to the higher content of dissolved $\mathrm{P}$ in the slurry, but rather to the stronger acidification of the soil and the indirect effect of this on properties related to soil $\mathrm{P}$ retention and release and therefore also to plant availability.

\section{Effects of slurry application time}

Application time had no effect on PU on either soil type (Table 4). Early application of moderately acidified slurry in a narrow band increased the concentration of WEP on the sandy soil, but it was not reflected in the DM yield. The lacking effect of application time could be explained by sorption to soil surfaces or immobilization of slurry $\mathrm{P}$, which may occur rapidly, i.e. within the first few days, making the differences between application of slurry two and 30 days before sowing negligible. Apparently, early application of slurry did not provide a better root growth environment in the narrow fertilizer band as hypothesized. On the contrary, early application of untreated slurry on the sandy loam showed no positive effect on DM yield compared to $0 \mathrm{P}$, which could be due to the low $\mathrm{WEP}_{\mathrm{i}}$ concentration in untreated slurry and the continuing poor growing conditions in the narrow manure band, irrespective of how early cattle slurry was applied. DM yields and PU as high as or higher than the 20P treatment were obtainable if strongly acidified slurry was applied in a narrow band on the sandy soil no matter the application time. Consequently, application 
of strongly acidified slurry in a narrow band and sowing do not have to be carried out at the same time, which might facilitate an earlier start of the slurry spreading season.

\section{Practical perspectives}

Injection of cattle slurry by tines at $24 \mathrm{~cm}$ distance before ploughing without considering the exact position of the following maize sowing is common practice in Denmark today. By this technique the slurry is still present in subsurface bands in soil after ploughing. Today GPS techniques allow positioning of seed rows precisely over previously applied slurry bands (Schröder et al. 2015), but the slurry has to be injected after ploughing/harrowing and before sowing. The present results indicate that this could preferably be done by placement by broad-banding under maize rows or by narrow-banding of acidified slurry on sandy soils. However, it will be necessary to find ways to handle compressed wheel tracks from slurry tankers especially on heavy soil types to establish a proper seed bed. Furthermore the results obtained here have to be verified under field conditions.

\section{Conclusion}

Application of slurry by placement in a broad band under a maize row increased maize $\mathrm{P}$ concentration at the five-leaf stage and increased the maize DM yield at the seven-leaf stage, irrespective of the acidification level and soil type. Thus, application of slurry in a broad band may provide a general better nutrient availability compared to injection of untreated slurry in a narrow band. Slurry acidification increased the concentration of dissolved inorganic P. However, only strongly acidified slurry increased DM yield and PU at the seven-leaf stage on the sandy soil compared to moderately acidified and untreated slurry, whereas strongly acidified slurry did not increase maize yield on the sandy loam. The results indicate that it was not the higher concentration of dissolved inorganic $\mathrm{P}$ in acidified slurry per se that improved DM yield and PU on the sandy soil, but rather an impact on soil $\mathrm{pH}$ and hence $\mathrm{pH}$-sensitive processes related to $\mathrm{P}$ availability. We did not find an additive effect of combining strongly acidified slurry with broad band application on maize yield in the early growing stages. Application of cattle slurry by narrow-band injection 30 days before sowing did not improve the maize growth response compared to narrow-band injection two days before sowing.

We conclude that mineral $\mathrm{P}$ starter fertilizer could potentially be replaced by broad-band injection of cattle slurry under maize rows or, on coarse sandy soil, by application of strongly acidified slurry injected in either narrow or broad bands. In this way the use of mineral $\mathrm{P}$ starter fertilizer might be obviated, and the P surpluses of silage maize cropping on dairy farms can be reduced.

Acknowledgements We thank the technical staff, especially Karin Dyrberg, Margit Paulsen and Lene Skovmose in the Department of Agroecology, Aarhus University, Denmark, for technical assistance. We thank Prof. Bent T. Christensen for valuable comments on a previous version of the paper. The study was financially supported by the Ministry of Environment and Food of Denmark (Green Development and Demonstration Programme (GUDP) project "Gylle-IT”).

\section{References}

Bache BW, Williams EG (1971) A phosphate sorption index for soils. J Soil Sci 22:289-301. doi:10.1111/j.1365-2389.1971. tb01617.x

Banderis A, Barter DH, Henderson K (1976) The use of polyacrylamide to replace carbon in the determination of "olsen's" extractable phosphate in soil. J Soil Sci 27:71-74. doi:10.1111/j.1365-2389.1976.tb01977.x

Barry D, Miller M (1989) Phosphorus nutritional requirement of maize seedlings for maximum yield. Agron J 81:95-99

Bittman S, Liu A, Hunt DE, Forge TA, Kowalenko CG, Chantigny MH, Buckley K (2012) Precision placement of separated dairy sludge improves early phosphorus nutrition and growth in corn (Zea mays L.). J Environ Qual 41:582-591. doi:10.2134/jeq2011.0284

Christensen ML, Hjorth M, Keiding K (2009) Characterization of pig slurry with reference to flocculation and separation. Water Res 43:773-783

EC (2014) Communication from the Commission to the European Parliament, The Council, The European Economic and Social Committee and the Committee of the Regions. Towards a circular economy: A zero waste programme for Europe/*COM/2014/0398 final*/

Engels C, Marschner H (1990) Effect of sub-optimal root zone temperatures at varied nutrient supply and shoot meristem temperature on growth and nutrient concentrations in maize seedlings (Zea mays L.). Plant Soil 126:215-225. doi:10.1007 /bf00012825

Fangueiro D, Hjorth M, Gioelli F (2015) Acidification of animal slurry-a review. J Environ Manag 149:46-56. doi:10.1016/j. jenvman.2014.10.001

Fordham AW, Schwertmann U (1977) Composition and reactions of liquid manure (Gülle), with particular reference to phosphate: 
II. Solid phase components. J Environ Qual 6:136-140. doi:10.2134/jeq1977.00472425000600020007x

Glaesner N, Kjaergaard C, Rubaek GH, Magid J (2011) Interactions between soil texture and placement of dairy slurry application: II. Leaching of phosphorus forms. J Environ Qual 40:344-351. doi:10.2134/jeq2010.0318

Grant C, Flaten D, Tomasiewicz D, Sheppard S (2001) The importance of early season phosphorus nutrition. Can J Plant Sci 81:211-224

Hinsinger P (2001) Bioavailability of soil inorganic P in the rhizosphere as affected by root-induced chemical changes: a review. Plant Soil 237:173-195. doi:10.1023/a:1013351617532

ISO 6878 (2004) ISO 6878: Water quality: Determination of phosphorus - Ammonium molybdate spectrometric method. 2 edn. ISO International Organization for Standardization

Kai P, Pedersen P, Jensen JE, Hansen MN, Sommer SG (2008) A whole-farm assessment of the efficacy of slurry acidification in reducing ammonia emissions. Eur J Agron 28:148-154. doi:10.1016/j.eja.2007.06.004

Kalra YP, Maynard DG (1991) Methods manual for forest soil and plant analysis. Information Report NOR-X-319. Northwest Region, Canada

Kirkham MB (2004) Principles of soil and plant water relations. Academic Press, Burlington

Klinglmair M, Lemming C, Jensen LS, Rechberger H, Astrup TF, Scheutz C (2015) Phosphorus in Denmark: national and regional anthropogenic flows. Resour Conserv Recycl 105(Part B):311-324. doi:10.1016/j.resconrec.2015.09.019

Knudsen L (2010) Økonomisk optimal anvendelse af startgødninger til majs. Sammendrag af indlæg til Plantekongres, Herning

Koroleff F (1983) Determination of phosphorus. In: Grasshof K (ed) Methods of seawater analysis. Verlag Chemie, Weinham, Germany, pp. 125-131

Kronvang B, Rubæk GH, Heckrath G (2009) International phosphorus workshop: diffuse phosphorus loss to surface water bodies - risk assessment, mitigation options, and ecological effects in river basins. J Environ Qual 38:1924-1929. doi:10.2134/jeq2009.0051

Lindsay WL, Vlek PLG, Chien SH (1989) Phosphate Minerals. In: Dixon JB, Weed SB (eds) Minerals in Soil Environments. SSSA Book Series, vol 1. Soil Sci Soc of Am J, Madison, WI, pp 1089-1130. doi:10.2136/sssabookser1.2ed.c22

Liu N, Jørgensen U, Lærke PE (2013) Quality determination of biomass for combustion: a new high-throughput microwave digestion method prior to elemental analysis by inductively coupled plasma-optical emission spectroscopy. Energy Fuel 27:7485-7488. doi:10.1021/ef4016747

Lynch JM (1980) Effects of organic-acids on the germination of seeds and growth of seedlings. Plant Cell Environ 3:255259. doi:10.1111/j.1365-3040.1980.tb00798.x

Magid J, Condron L, Tiessen H (1996) Dynamics of organic phosphorus in soils under natural and agricultural ecosystems. In: Piccolo A (ed) Humic substances in terrestrial ecosystems. Elsevier, Amsterdam, pp. 429-466

Mollier A, Pellerin S (1999) Maize root system growth and development as influenced by phosphorus deficiency. J Exp Bot 50:487-497

Murphy J, Riley JP (1962) A modified single solution method for the determination of phosphate in natural waters. Anal Chim Acta 27:31-36. doi:10.1016/S0003-2670(00)88444-5
Nadeem M, Mollier A, Morel C, Vives A, Prud'homme L, Pellerin S (2011) Relative contribution of seed phosphorus reserves and exogenous phosphorus uptake to maize (Zea mays L.) nutrition during early growth stages. Plant Soil 346:231-244. doi:10.1007/s11104-011-0814-y

Oberson A, Joner EJ (2005) Microbial turnover of phosphorus in soil. In: Turner BL, Frossard E, Baldwin D (eds) Organic phosphorus in the environment. CAB International, Wallingford, pp. 133-164

Pagliari PH (2014) Variety and solubility of phosphorus forms in animal manure and their effects on soil test phosphorus. In: He Z, Zhang $\mathrm{H}$ (eds) Applied manure and nutrient chemistry for sustainable agriculture and environment. Springer, pp 141-161

Petersen J, Høgh-Jensen H, Rubæk GH (2010) Phosphorus fertilization of maize seedlings by side-band injection of animal slurry. Paper presented at the Ramiran International Conference of the FAO ESCORENA Network on the Recycling of Agricultural Municipal and Industrial Residues in Agriculture

R Development Core Team (2015) R: A Language and Environment for Statistical Computing

Rubæk GH, Sibbesen E (1995) Soil phosphorus dynamics in a long-term field experiment at Askov. Biol Fertil Soils 20:8692. doi:10.1007/bf00307847

Rubæk GH, Kristensen K, Olesen SE, Østergaard HS, Heckrath G (2013) Phosphorus accumulation and spatial distribution in agricultural soils in Denmark. Geoderma 209-210:241-250. doi:10.1016/j.geoderma.2013.06.022

Sawyer JE, Hoeft RG (1990) Effect of injected liquid beef manure on soil chemical properties and corn root distribution. J Prod Agric 3:50-55. doi:10.2134/jpa1990.0050

Schröder JJ, Vermeulen GD, van der Schoot JR, van Dijk W, Huijsmans JFM, Meuffels GJHM, van der Schans DA (2015) Maize yields benefit from injected manure positioned in bands. Eur J Agron 64:29-36. doi:10.1016/j. eja.2014.12.011

Shepherd JG, Kleemann R, Bahri-Esfahani J, Hudek L, Suriyagoda L, Vandamme E, van Dijk KC (2016) The future of phosphorus in our hands. Nutr Cycl Agroecosyst 104: 281-287. doi:10.1007/s10705-015-9742-1

Sommer S, Husted S (1995) The chemical buffer system in raw and digested animal slurry. J Agric Sci 124:45-53

Sommer SG, Kjellerup V, Kristjansen O (1992) Determination of total ammonium nitrogen in pig and cattle slurry - sample preparation and analysis. Acta Agri Scan, Sect B, Soil and Plant Sci 42:146-151

Sørensen P (1998) Carbon mineralization, nitrogen immobilization and $\mathrm{pH}$ change in soil after adding volatile fatty acids. Eur J Soil Sci 49:457-462. doi:10.1046/j.13652389.1998.4930457.x

Sørensen NK, Bülow-Olsen A (1994) Fælles arbejdsmetoder for jordbundsanalyser. Plantedirektoratet, Landbrugsministeriet

Syers JK, Johnston AE, Curtin D (2008) Efficiency of soil and fertilizer phosphorus use: reconciling changing concepts of soil phosphorus behaviour with agronomic information. FAO Fertilizer and Plant Nutrition Bulletin, vol 18

van Dijk KC, Lesschen JP, Oenema O (2016) Phosphorus flows and balances of the European Union member states. Sci Total Environ 542(Part B):1078-1093. doi:10.1016/j. scitotenv.2015.08.048 
White PJ (2006) Ion uptake mechanisms of individual cells and roots: short-distance transport. In: Marschner H (ed) Mineral nutrition of higher plants, 2nd edn. Academic Press, London, pp. $7-47$
Withers PJA, van Dijk KC, Neset T-SS, Nesme T, Oenema O, Rubæk GH, Schoumans OF, Smit B, Pellerin S (2015) Stewardship to tackle global phosphorus inefficiency: the case of Europe. Ambio 44:193-206. doi:10.1007/s13280-014-0614-8 